\title{
Announcements
}

\section{Xlth European Symposium on Hormones and Cell Regulation}

Sainte-Odile (near Strasbourg), France, September 29 to October 2, 1986 Sponsored by ‘Institut National de la Santé et de la Recherche Médicale’ (Inserm)

The aim of this Symposium is to present reviews of recent advances in general lectures and communications of recent unpublished results in posters, both being analyzed at length in general discussions. The organizers try to have the discussions and thus the audience as interdisciplinary as possible. Free time in the afternoons allows opportunity for informal discussions, visits, and hiking. The Symposium is being held in a hotel associated with a magnificent monastery situated on a hill top commanding superb views of Alsace and the Rhine valley.

Main Topics of the 1986 Conference

Regulation through derivatives of phosphoinositides, GTP-binding proteins in signal transduction, control of cell proliferation, control of gene expression, thyroid.

Speakers will include

J. Nunez (Paris), W.J. Irvine (Cambridge), P. Parker (London), P.T. Chambon (Strasbourg), H.H. Samuels (New York), J. Mallet (Paris), R. Pictet (Paris), B.D. Gomperts (London), P. Gierschik (Heidelberg), E.G. Lapetina (Research Triangle Park), J.E. Du-mont (Brussels), S. Jard (Montpellier), R. Kahn (Boston), J. Pouys-segur (Nice), R. Bravo (Heidelberg), G. Vassart (Brussels), D. de Wied (Utrecht), G. Schultz (Berlin), E. Milgrom (Paris), S. Green (Strasbourg), H. Jackie (Tubingen).

Information

A limited number of fellowships is available to help young investigators who have a special interest in the program and who otherwise cannot attend the Symposium. It is being tried to find money for travel grants for participants from the United Kingdom. Attendance is limited to 120 persons on a first come first registered basis. Participants are encouraged to present find money for travel grants for participants

Detailed information on the program, registration, etc. is available from the Secretariat: Dr. J.E. Dumont, Institute of Interdisciplinary Research, Faculty of Medicine, Free University of Brussels, Campus Erasme, 8008, route de Lennik, B-1070 Brussels, Belgium.

Organizers

E. Carafoli (Zurich), R.H. Denton (Bristol), J.E. Dumont (Brussels), B. Hamprecht (Würzburg), R.J.B. King (London), F. Morel (Paris), J. Nunez (Paris), G. Schultz (Berlin), H.J. van der Molen (Rotterdam). 
International Meeting on Hormonal Therapy of Prostatic Diseases: Basic and Clinical Aspects Milano, Italy, April 5-8, 1987

The International Symposium on 'Hormonal Therapy of Prostatic Diseases' will be planned by an International Scientific Committee formed by A. Bartke (USA), N. Bruchowsky (Canada), L. Denis (Belgium), J. Geller (USA), M. Motta (Italy), J. Robinson (UK), M. Serio (Italy), and K.D. Voigt (Germany).

The program will include invited lecturers as well as sessions of free communications and/or poster presentations on the following topics: (1) the normal prostate: morphological, biochemical and hormonal aspects; (2) the pathological prostate (BPH, carcinoma, etc.): morphological, biochemical and hormonal aspects; (3) therapeutic approaches in prostatic diseases (animal and human studies).

For further infor serio, Department of Endocrinology, University of Milano, 21, Via Andrea del Sarto, 20129 Milano, Italy, Tel. 02 - 7385 351. For registration, travel and logistic information, please contact the Organizing Secretariat. Address: OIC, Largo Corsia dei Servi, 11, 20121 Milano, Italy, Tel. 02 - 7083 57/70 8419 